\title{
Development studies of captopril certified reference material
}

\author{
Raquel Nogueira ${ }^{1 *}$, Eliane Cristina Pires do Rego ${ }^{1}$, Marcus Vinicius Barreto Sousa ${ }^{1}$, Wagner \\ Wollinger ${ }^{1}$, Thaís Elias da Silva ${ }^{1}$, Gabriela Fernandes Moreira ${ }^{2}$, Juliano Smanioto Barin ${ }^{1}$, \\ Luciane Varini Laporta ${ }^{1}$, Márcia Foster Meskoํㅜ, Celso Figueiredo Bittencourt ${ }^{1}$, Janaína Marques \\ Rodrigues $^{1}$, Valnei Smarçaro da Cunha ${ }^{1}$
}

\author{
${ }^{1}$ Brazilian National Institute of Metrology, Standardization and Industrial Quality (Inmetro), Chemical Metrology Division \\ (Dquim), Organic Analysis Laboratory (Labor), ${ }^{2}$ Brazilian National Institute of Metrology, Standardization and Industrial
} Quality (Inmetro), Materials Metrology Division (Dimat)

\begin{abstract}
This paper describes the studies performed with the candidate Certified Reference Material (CRM) of captopril, the first CRM of an active pharmaceutical ingredient (API) in Brazil, including determination of impurities (organic, inorganic and volatiles), homogeneity testing, short- and long-term stability studies, calculation of captopril content using the mass balance approach, and estimation of the associated measurement uncertainty.
\end{abstract}

Uniterms: Captopril/qualitative analysis. Medicines/Certified Reference Standards. Medicines/analytical quality control. High Pressure Liquid Chromatography (HPLC)/qualitative analysis. Medicines/ contamination.

Este artigo descreve os estudos realizados com o candidato a Material de Referência Certificado (MRC) de captopril, primeiro MRC de fármacos no Brasil, incluindo a determinação de impurezas (orgânicas, inorgânicas e voláteis), testes de homogeneidade, testes de estabilidade de curta e longa duração, cálculo do teor de captopril por balanço de massa e estimativa da incerteza de medição associada ao valor certificado.

Unitermos: Captopril/análise qualitativa. Fármacos/Padrões de Referência. Fármacos/controle analítico de qualidade. Cromatografia Líquida de Alta Eficiência/análise qualitativa. Medicamentos/contaminação.

\section{INTRODUCTION}

The use of Reference Materials (RM) is a common practice in the pharmaceutical area, both for qualitative and quantitative purposes, in order to comply with the pharmacopeial monographs. Nowadays, these pure substances, also called Reference Standards, can be easily purchased from different pharmacopeias.

An evaluation of RMs from a metrological point of view indicates that their use cannot provide traceability of measurement results to the International System of Units (SI). Metrological traceability is a requirement of the ISO 17025 standard (ISO 17025:2005) and corresponds to "an unbroken chain of comparisons to stated references, usu-

*Correspondence: R. Nogueira. Instituto Nacional de Metrologia, Normalização e Qualidade Industrial, Divisão de Metrologia Química, Laboratório de Análise Orgânica, Av. Nossa Senhora das Graças, 50 - Xerém, 25250-020 - Rio de Janeiro - RJ, Brazil. E-mail: rnogueira@inmetro.gov.br ally national or international standards, all having stated uncertainties" (Duewer et al., 2004; ISO guide 30:1992; Eurachem/Citac, 2000; JCGM, 2008). In the absence of such standards, the Reference Materials can be traceable to physical or chemical properties (Duewer et al., 2004).

On the other hand, Certified Reference Materials (CRM) can provide measurement traceability and therefore they are correctly used to assign values to other materials, as well as for calibration, quality control and method validation (ISO guide 35:2006).

CRMs are high purity substances, stable, homogeneous, and fully characterized regarding their composition (Duewer et al., 2004), which are accompanied by a certificate or similar type of document declaring the specified value of a given property (the content of the active pharmaceutical ingredient, API, in case of pharmaceutical substances) and the associated measurement uncertainty (ISO guide 30:1992, ISO guide 30:1992/Amd. 1:2008, 
ISO guide 35:2006; JCGM, 2008). The requirements for production and certification of Certified Reference Materials are set by the ISO guides 34:2009 and 35:2006 and include the characterization of the material, homogeneity testing, short- and long-term stability studies, as well as the estimation of the measurement uncertainty. For pharmacopoeial standards, the ISO guide 35:2006 indicates that a different and specific approach may be used, provided the general principles of the guide are followed, while the ISO guide 34:2009 states that for most pharmacopoeial assay standards "the uncertainties of the assigned values are not stated, since they are considered to be negligible in relation to the defined limits of the method-specific assays for which they are used".

The trueness of this last statement, which appears in the ISO guide 34 at least since its $2^{\text {nd }}$ edition (2000), had previously come under question (Kuselman, Weisman, Wegscheider, 2003). Additionally, an international tendency to produce CRMs in the pharmaceutical area is evident, although their availability remains very limited. The United States Pharmacopeia (USP), for instance, whose Reference Standards have been available since 1926 (Williams et al., 2006), developed its first CRM in September 2008: dextromethorphan hydrobromide. In the following year, three other CRMs were made available by the USP (teophylline, phenytoin and carbamazepine) (The United States Pharmacopeial Convention, 2010). Therefore, increasing demand for Certified Reference Materials in the pharmaceutical area is likely, which in the near future may be increasingly provided by pharmacopeias or National Metrology Institutes (NMIs).

In Brazil, although the National Health Surveillance Agency (Anvisa) still does not legally require the use of CRMs, the National Institute of Metrology, Normalization and Industrial Quality (Inmetro) started a pioneer project to develop the first Brazilian Certified Reference Material in the pharmaceutical area, and captopril CRM has been available on the market since April 2010.

The mass balance approach has been chosen to determine captopril content, since this procedure was reported to provide standard deviations up to 10 times lower compared to those obtained using the traditional assay methods for APIs (Hofer, Olsen, Rickard, 2007), thus leading to lower associated measurement uncertainties.

This paper describes the studies performed with the candidate CRM of captopril, including quantification of the organic, inorganic and volatile impurities, evaluation of the between-bottle homogeneity, and of the short- and long-term stabilities, the use of the mass balance approach for calculation of captopril content, as well as estimation of associated measurement uncertainty.

\section{MATERIALS AND METHODS}

\section{Instrumentation}

A Shimadzu high performance liquid chromatograph (HPLC), equipped with quaternary pump LC-20AT, on-line degasser DGU-20A 3 DGU-20A $_{5}$, auto-sampler SIL-20A/20AC, photodiode array detector SPD-20A and interface CBM-20A/20A, was used for the determination of related substances. The data were processed using the software Lab Solution. The analysis conditions used were: mobile phase methanol - phosphoric acid $0.11 \%$ (55:45, $\mathrm{v} / \mathrm{v}$ ), flow - rate $1 \mathrm{~mL} / \mathrm{min}$, UV detection at $220 \mathrm{~nm}$. The HPLC column was RP18, $25 \mathrm{~cm} \times 4.6 \mathrm{~mm}$ i.d., $5 \mu \mathrm{m}$, Supelcosil (Supelco), to which a pre-column RP18, 4.6 mm i.d., $5 \mu \mathrm{m}$ (Varian) was attached. The same column was used for the LC-MS experiments, using a HPLC coupled to a triple quadrupole (1200 L Quadrupole MS/MS, Varian), methanol - $10 \mathrm{mM}$ formic acid $(55: 45, \mathrm{v} / \mathrm{v})$ and methanol $-0.1 \%$ TFA $(55: 45, \mathrm{v} / \mathrm{v})$ as mobile phases and $0.2 \mathrm{~mL} / \mathrm{min}$ as the flow-rate.

A Karl Fischer coulometer 831 Metrohm equipped with an oven sample processor 774 Metrohm and Tiamo 1.2 software was used for water determination, using an oven temperature of $80^{\circ} \mathrm{C}$, extraction time of $300 \mathrm{~s}$ and nitrogen-flow of $115 \mathrm{~mL} / \mathrm{min}$. The Differential Scanning Calorimetry measurements were performed using a DSC Q1000 (TA Instruments) according to Moreira et al. (2010). For the gravimetric preparation of samples, an analytical Shimadzu balance, model AUW 220D, with resolution $0.01 \mathrm{mg}$ was used.

\section{Samples and reagents}

The studies were performed using samples of the first batch of Inmetro CRM of captopril (MRC 09.1/09.001). Initially, the captopril was tested according to the F. Bras. IV ed. monograph and the results confirmed that it was a high purity material and suitable to become a candidate Certified Reference Material. The material was then packed in portions of $525 \mathrm{mg}$ (nominal mass: $500 \mathrm{mg}$, excess of 5\%) in amber glass flasks, under controlled temperature and humidity. The flasks were sealed with rubber caps and aluminum seals and identified with labels containing the CRM name and a serial number. Weight control was performed according to the F. Bras. IV ed. and the following results were obtained: average weight: $530.41 \mathrm{mg}(n=10)$, RSD $0.91 \%$, greatest weight deviation from the average: $1.5 \%$. All the tests described in this article were performed after the material had been packaged in its final form. 
USP Reference Standards of captopril (batch $\mathrm{H} 09120 \mathrm{H}, 100.0 \%$ ) and of captopril disulfide (batch H0F251, 99.0\%) were also analyzed by HPLC for comparison and were not dried before use.

For HPLC analysis, methanol HPLC grade (Tedia), o-phosphoric acid 85\% w/w for analysis (Merck) and water type I were used. A Coulomat AG solution (RiedeldeHaen) was used for Karl Fischer coulometric titration,

\section{CRM characterization}

The procedure chosen to determine the content of active pharmaceutical ingredients in the first Inmetro batch of captopril CRM was the mass balance approach (eq. 1).

Captopril (\%) $=100 \%-\Sigma$ organic impurities (\%) $\Sigma$ inorganic impurities (\%) - $\Sigma$ volatiles (water and solvents) (\%)

The organic impurities were determined by HPLC according to the related substances test in the F. Bras. IV ed. (2002) monograph. Solutions containing $500 \mu \mathrm{g} / \mathrm{g}$ and $10 \mu \mathrm{g} / \mathrm{g}$ were prepared in triplicate from each CRM flask, and each solution was injected three times into the HPLC system. The HPLC method was validated and these studies revealed that the captopril was very unstable in solution, with formation of increasing amounts of its dimmer captopril disulfide, as previously reported (Stulzer, Silva, 2006). Therefore, the accurate quantification of organic impurities required the analysis of solutions immediately after their preparation.

The content of each organic impurity in the captopril samples was determined according to eq. 2 :

$$
[\text { org }]=\frac{A_{\text {imp }}}{\left(A_{\text {cap dil }} D F\right)+\sum A_{\text {imp }}}
$$

where: $[\mathrm{org}]=$ content of each organic impurity in the captopril samples; $A_{i m p}=$ peak area of each organic impurity $\left(500 \mu \mathrm{g} / \mathrm{g}\right.$ solution of captopril); $A_{\text {capt dil }}=$ peak area of captopril $(10 \mu \mathrm{g} / \mathrm{g}$ solution of captopril $) ; D F=$ dilution factor from the $500 \mu \mathrm{g} / \mathrm{g}$ to the $10 \mu \mathrm{g} / \mathrm{g}$ solution; $\Sigma A_{\text {imp }}=$ sum of peak areas of all organic impurities

The inorganic impurities were determined using the residue of ignition test (ashing) according to the F. Bras. IV ed. Although more precise and sensitive methods are available to quantify inorganic metals, including AAS, ICP-AES, and ICP-MS, the determination of inorganic residues by ashing has previously been employed for the development of CRMs (Le Goff, Wood, 2009; Mathkar et al., 2009), since it is a gravimetric test which easily estimates the total content of inorganics in a sample.

The volatiles were determined by the loss on drying (LOD) test, performed at $60^{\circ} \mathrm{C}$ under vacuum for 3 hours, according to the F. Bras. IV ed. The results were compared to the water content determined by coulometric Karl Fischer titration (oven method).

\section{Homogeneity studies}

The between-bottle variation was evaluated using 12 CRM flasks selected at random. The HPLC analysis was done as previously described and the captopril content was determined by mass balance according to eq. 1 .

Additionally, the homogeneity was also evaluated by oxidation-reduction titration with potentiometric endpoint, according to the assay method in the F. Bras. IV ed. monograph. This study used 24 samples, prepared in triplicate.

\section{Short- and long-term stability studies}

For the short-term stability study, 8 flasks of CRM, selected at random, were subjected simultaneously to a temperature of $50{ }^{\circ} \mathrm{C}$. On pre-determined days, one flask was taken out of the oven and individually analyzed (classical design). Solutions containing $500 \mu \mathrm{g} / \mathrm{g}$ and $10 \mu \mathrm{g} / \mathrm{g}$ were prepared in triplicate from each CRM flask, and each solution was injected three times into the HPLC system. Three other CRM flasks, not exposed to the temperature of $50{ }^{\circ} \mathrm{C}$, were analyzed (solutions prepared in triplicate, three injections per solution) and used as controls. The captopril content was calculated by mass balance.

For the long-term stability evaluation, the samples were kept at the recommended storage conditions $\left(20-25^{\circ} \mathrm{C}\right)$. The analysis was performed four times throughout the year in which the certification study was performed (namely on the $1^{\text {st }}, 11^{\text {th }}, 30^{\text {th }}$ and $38^{\text {th }}$ weeks). At each timepoint, three flasks were analyzed in triplicate, whereby each solution was injected three times into the HPLC. After the $38^{\text {th }}$ week, a monitoring program of the CRM samples was started.

\section{Estimation of measurement uncertainties}

The uncertainty calculation was performed according to the Eurachem/Citac guide (Eurachem/Citac, 2000). The relevant uncertainty sources are shown in the cause and effect diagram (Figure 1). Based on eq. 1, the uncertainties due to the determination of organic impurities $\left(u_{\text {org }}\right)$, of inorganic impurities $\left(u_{\text {inorg }}\right)$ and of volatiles $\left(u_{v o l}\right)$ were included. Additionally, the between-bottle variation 
uncertainty $\left(u_{b b}\right)$ and the long-term stability uncertainty $\left(u_{l t s}\right)$ were considered as uncertainty components. As explained later, the short-term stability uncertainty $\left(u_{s t s}\right)$ was not taken into account.

The uncertainty sources for the determination of organic impurities $\left(u_{\text {org }}\right)$ were basically the parameters of eq. 2, as can be seen in Figure 1. The dilution factor (DF) covered the influence of the calibration of the analytical balance used for gravimetric preparation of samples, while the peak areas covered the influences of the HPLC system, the method, and of the captopril instability in solution. The combined uncertainty due to the determination of organic impurities $\left(u_{\text {org }}\right)$, considering independent variables, was calculated according to eq. 3 .

$$
u_{\text {org }}=\sqrt{\sum_{i=1}^{N}\left(\delta_{\text {org }} / \delta_{x i}\right)^{2} u_{x i}^{2}}
$$

where: $\delta_{\text {org }} / \delta_{x i}=$ sensitivity coefficient or partial differential of content of organic impurities with respect to each uncertainty component $\mathrm{x}_{\mathrm{i}} ; u_{x i}=$ uncertainties due to components $\mathrm{x}_{\mathrm{i}}$

The combined standard uncertainties $\left(u_{c}\right)$ due to the determination of inorganic impurities or to the determination of volatiles (hereafter called $u_{\text {inorg }}$ and $u_{\text {vol }}$, respectively) were calculated according to eq. 4 , which took into account the uncertainty due to the repeatability (equation term containing the standard deviation, SD) and the uncertainty due to the analytical balance (equation term containing the expanded uncertainty $U$ for the analytical balance).

$$
u_{c}=x \sqrt{(S D / \sqrt{n} x)^{2}+(U / k m)^{2}}
$$

where: $u_{c}=$ combined standard uncertainty (\%); $S D=$ standard deviation; $n=$ number of measurements; $x=$ mean of results; $U=$ expanded uncertainty for the analytical balance $(\mathrm{mg}) ; k=$ coverage factor $(k=2) ; m=$ average weighed mass (mg).

The uncertainty due to between-bottle (in)homogeneity $\left(u_{b b}\right)$ was calculated by eq. 5 , according to ISO guide 35 .

$$
u_{b b}=\sqrt{\left(M S_{b e t w e e n}-M S_{\text {within }}\right) / n}
$$

where: $M S_{\text {between }}=$ Mean square between groups (variation between units); $M S_{\text {within }}=$ Mean square within groups (variation within the units); $n=$ number of replicates.

The short-term stability uncertainty $\left(u_{s t}\right)$ was calculated by eq. 6 , which was also used to estimate the longterm stability uncertainty $\left(u_{l t s}\right)$.

$$
u_{s t s}=s_{(b 1)} t
$$

where: $u_{s t s}=$ uncertainty due to short-term stability; $s_{(b l)}=$ uncertainty of the slope (equivalent to standard error in $b_{1}$ in regression analysis); $t=$ time.

Finally, the combined standard uncertainty associated with the CRM property value $\left(u_{C R M}\right)$ was calculated

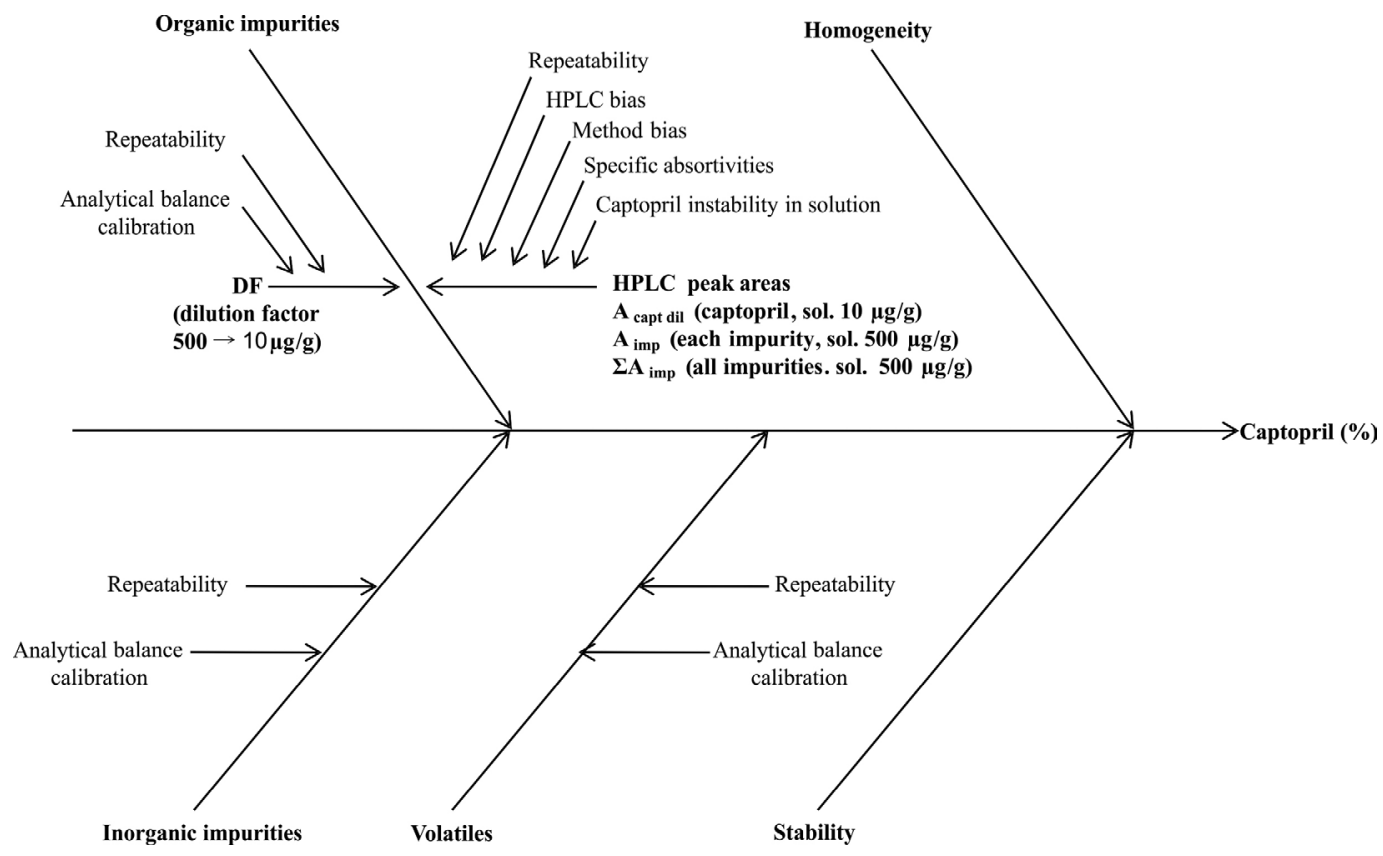

FIGURE 1 - Cause and effect diagram. 
according to the law of propagation of uncertainties, which consists of "the square root of the total variance obtained by combining all the uncertainty components" (Eurachem/ Citac, 2000) (eq. 7), considered to be independent variables and expressed in the same unit.

$u_{C R M}=\sqrt{u_{o r g}{ }^{2}+u_{\text {inorg }}{ }^{2}+u_{v o l}{ }^{2}+u_{b b}{ }^{2}+u_{l t s}{ }^{2}}$

The expanded uncertainty $(U)$, which is "the interval within which the value of the measurand is believed to lie with a higher level of confidence" (Eurachem/Citac, 2000) was calculated according to eq. 8 .

$$
U=u_{C R M} k
$$

where: $k=$ coverage factor $(k=2$ for a $95 \%$ confidence level; ABNT/Inmetro, 2003).

\section{RESULTS AND DISCUSSION}

The certification steps after material evaluation and packaging, were as follows:

1. CRM characterization:

1.1. Determination of organic impurities;

1.2. Determination of inorganic impurities;

1.3. Determination of volatiles.

2. Homogeneity studies;

3. Short-term stability studies;

4. Long-term stability studies;

5. Mass balance.

In all steps, the associated measurement uncertainties were estimated.

\section{Captopril CRM characterization}

\section{Determination of organic impurities}

The quantification of the related substances of captopril according to eq. 2 has been chosen based on the following aspects: a) it is not an assay calculation and therefore does not rely on the use of the Certified Reference Materials of captopril and captopril disulfide, which are not available and could not be used to guarantee traceability; b) the single factor analysis of variance (Anova) of the normalized mean peak areas of seven individual solutions containing $10 \mu \mathrm{g} / \mathrm{g}$ of captopril USP reference standard or $10 \mu \mathrm{g} / \mathrm{g}$ of captopril disulfide USP reference standard, prepared on different days and injected six times each, indicated no significant difference between the two groups (captopril and disulfide), since F value $2.3105<$ F crit 4.7472 ; and c) the peak area of captopril and impurities are of the same order of magni- tude, since the peak area of captopril is obtained from the $10 \mu \mathrm{g} / \mathrm{g}$ solution and corrected by the dilution factor (DF).

The content of related substances determined by HPLC was $0.313264 \%$, of which $0.259449 \%$ (ca. $82 \%$ ) was represented by the main impurity captopril disulfide. These results were in accordance with the F. Bras. IV ed. acceptance criteria for captopril (maximum of $1.0 \%$ captopril disulfide and $2.0 \%$ total organic impurities) and were confirmed by three further measurements performed using the same procedure, as described later in the longterm stability studies. The combined uncertainty due to the determination of related substances $\left(u_{\text {org }}\right)$ calculated according to eq. 3 was $0.036149 \%$.

Additionally, captopril was also analyzed by high performance liquid chromatography coupled to mass spectrometry (LC-MS), in order to identify the unknown impurities observed by HPLC-DAD, eluted before the captopril peak and also between the peaks of captopril and disulfide (Figure 2), although their contents were below $0.05 \%$, which is the lowest threshold proposed by the ICH for the identification of unknowns (ICH, 1994). The MS detection considered the molecular weights of the captopril impurities described in the literature (LGC, 2010). The following signals could be clearly identified: $[\mathrm{M}+\mathrm{H}]^{+}$218: captopril, $[\mathrm{M}+\mathrm{H}]^{+}$433: captopril disulfide, $[\mathrm{M}+\mathrm{H}]^{+} 70$ and 116: captopril fragments. Concerning the impurities, despite using the $0.1 \%$ formic acid containingphase, which resulted in stronger MS response compared to the $0.1 \%$ TFA phase, it was still not possible to identify the unknown impurities of captopril.

\section{Determination of inorganic impurities}

The content of inorganic impurities determined by the residue of ignition test was $0.02398 \%(n=9)$ (Table I), which is in accordance with the specified limit of $0.2 \%$ in the F. Bras. IV ed. monograph of captopril. The calculated value of $u_{\text {inorg }}$ (eq. 4) was $0.002976 \%$ (considering $m=973.089 \mathrm{mg}, U=0.06 \mathrm{mg}$ and $k=2$ ).

\section{Determination of volatiles}

The content of volatiles in the captopril CRM determined by the loss on drying (LOD) test was $0.097744 \%$ $(n=10)$, as shown in Table II, which is in accordance with the specified limit of $1.0 \%$ for the loss on drying test described in the F. Bras. IV ed. monograph of captopril. The uncertainty $\left(u_{v o l}\right)$ estimated by eq. 4 was $0.004889 \%$ (considering $m=501.3 \mathrm{mg}, U=0.06 \mathrm{mg}$ and $k=2$ ).

The water content determined by Karl Fischer coulometric titration was $0.025183 \%(n=10, \mathrm{u}=0.000800 \%)$, a lower value compared to the result of the loss on drying (LOD) test. This difference may be explained by the fact 

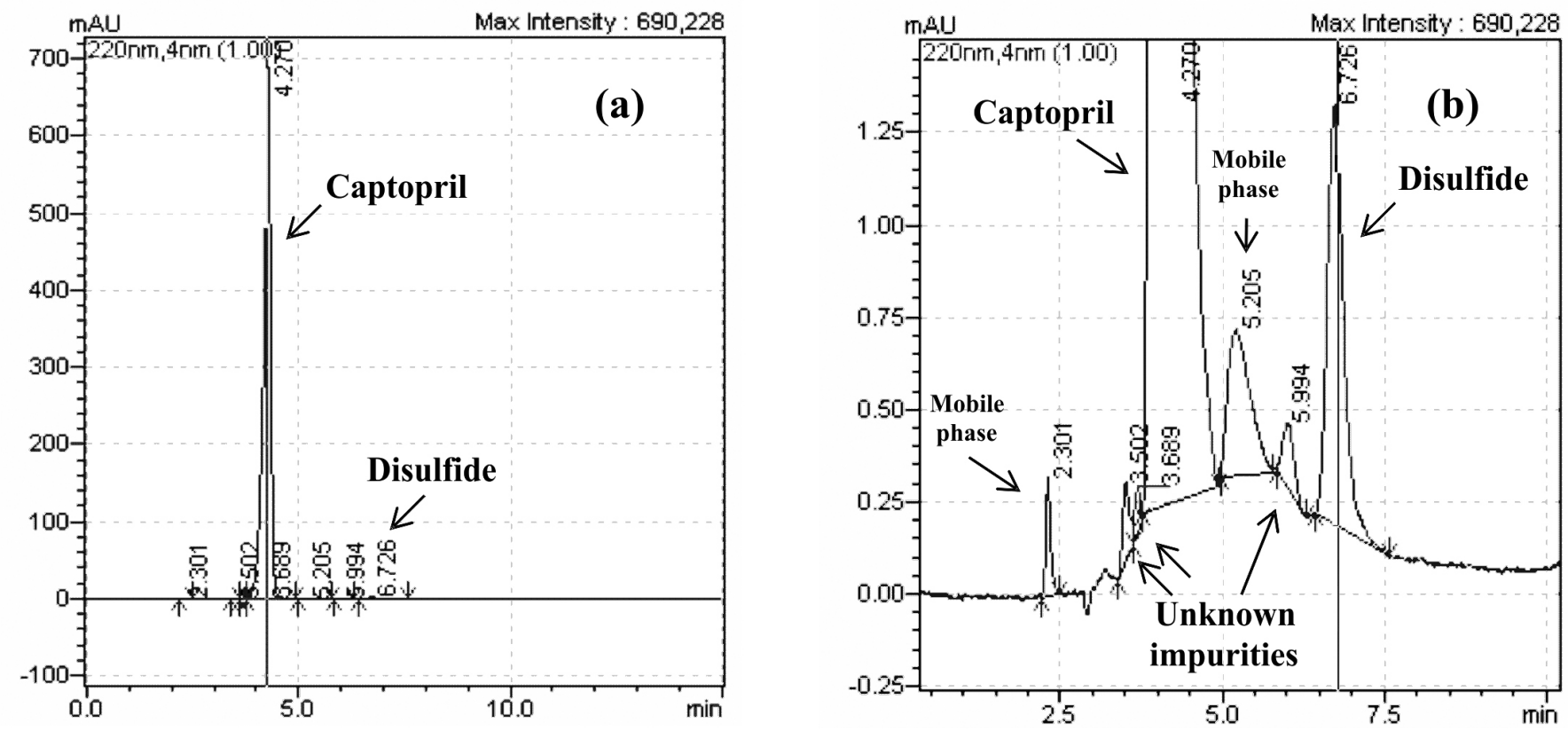

FIGURE 2 - HPLC-DAD chromatogram for captopril CRM (related substances test) (a) and enlargement (b). Experimental conditions: mobile phase methanol - phosphoric acid 0.11\% (55:45, v/v), flow-rate $1 \mathrm{ml} / \mathrm{min}, \mathrm{UV}$ detection at $220 \mathrm{~nm}$, HPLC column RP18, $5 \mu \mathrm{m}, 25 \mathrm{~cm}$ x $4.6 \mathrm{~mm}$ i.d.; pre-column RP18, $5 \mu \mathrm{m}, 4.6 \mathrm{~mm}$ i.d.

TABLE I - Results for the residue of ignition test

\begin{tabular}{lcc}
\hline & Weighed mass (g) & Results (\%) \\
\hline 1 & 0.9306 & 0.03224 \\
2 & 0.9449 & 0.01058 \\
3 & 0.9799 & 0.03062 \\
4 & 0.9675 & 0.02067 \\
5 & 0.9705 & 0.03091 \\
6 & 0.9953 & 0.02009 \\
7 & 0.9869 & 0.03040 \\
8 & 0.9886 & 0.01012 \\
9 & 0.9936 & 0.03019 \\
\hline & Average (x) & $\mathbf{0 . 0 2 3 9 8 0}$ \\
& SD & 0.00893 \\
& RSD (\%) & 37.23 \\
& $N$ & 9 \\
\hline
\end{tabular}

that the Karl Fischer method is insensitive to residual solvents, therefore the results obtained by the Karl Fischer and the loss on drying tests may not be comparable (Smith, Webb, 2007).

\section{Homogeneity studies}

The captopril contents of the samples for homogeneity evaluation were calculated by mass balance (eq. 1)
TABLE II - Results for loss on drying test

\begin{tabular}{lcc}
\hline & Weighed mass (g) & Results (\%) \\
\hline 1 & 0.5023 & 0.09944 \\
2 & 0.5009 & 0.07979 \\
3 & 0.5014 & 0.07971 \\
4 & 0.5182 & 0.09639 \\
5 & 0.5001 & 0.09988 \\
6 & 0.5047 & 0.09897 \\
7 & 0.4999 & 0.11988 \\
8 & 0.4838 & 0.12386 \\
9 & 0.5016 & 0.09958 \\
10 & 0.5001 & 0.07992 \\
\hline & Average (x) & $\mathbf{0 . 0 9 7 7 4 4}$ \\
& SD & 0.01546 \\
& RSD (\%) & 15.82 \\
& $N$ & 10 \\
\hline
\end{tabular}

and the results are shown in Table III. Considering the instability of captopril in solution according to the method validation studies, the sample solutions were injected into the HPLC system just after preparation, and therefore the randomized order of analysis recommended by the ISO guide 35:2006 could not be used. However, no trends were observed in the results related to the order of injection of samples (Figure 3a) or to the flask number (Figure 3b), 
TABLE III - Homogeneity results

\begin{tabular}{lccccccc}
\hline & Sample nr. & $\begin{array}{c}\text { Replicate 1 } \\
(\mathbf{\%})\end{array}$ & $\begin{array}{c}\text { Replicate 2 } \\
(\mathbf{\%})\end{array}$ & $\begin{array}{c}\text { Replicate 3 } \\
(\mathbf{\%})\end{array}$ & $\begin{array}{c}\text { Average } \\
(\mathbf{\%})\end{array}$ & $\begin{array}{c}\text { SD } \\
(\mathbf{\%})\end{array}$ & $\mathbf{n}$ \\
\hline 1 & 16 & 99.57 & 99.58 & 99.57 & 99.57 & 0.0013 & 3 \\
2 & 180 & 99.57 & 99.57 & 99.54 & 99.56 & 0.0191 & 3 \\
3 & 446 & 99.59 & 99.52 & 99.58 & 99.56 & 0.0351 & 3 \\
4 & 76 & 99.59 & 99.55 & 99.53 & 99.56 & 0.0310 & 3 \\
5 & 264 & 99.59 & 99.59 & 99.59 & 99.59 & 0.0014 & 3 \\
6 & 416 & 99.59 & 99.57 & 99.56 & 99.57 & 0.0165 & 3 \\
7 & 61 & 99.60 & 99.59 & 99.58 & 99.59 & 0.0090 & 3 \\
8 & 286 & 99.60 & 99.60 & 99.59 & 99.60 & 0.0054 & 3 \\
9 & 438 & $(1)$ & 99.61 & 99.61 & 99.61 & 0.0023 & 2 \\
10 & 11 & 99.55 & 99.56 & $(1)$ & 99.55 & 0.0060 & 2 \\
11 & 318 & 99.55 & 99.57 & 99.55 & 99.56 & 0.0132 & 3 \\
12 & 468 & 99.56 & 99.56 & 99.56 & 99.56 & 0.0035 & 3 \\
\hline \multicolumn{7}{c}{ Average: } \\
\hline
\end{tabular}

${ }^{(1)}$ Error in the HPLC injection

which was designated sequentially during the packaging operation of the CRM.

The single-factor analysis of variance of the captopril contents resulted in a mean square between groups $\left(\mathrm{MS}_{\text {between }}\right)$ of 0.000981 and a mean square within groups $\left(\mathrm{MS}_{\text {within }}\right)$ of 0.000287 . Using eq. 5 , the uncertainty due to between-bottle (in)homogeneity $\left(u_{b b}\right)$ was estimated to be $0.015218 \%$.

The homogeneity of captopril CRM was also evaluated by oxidation-reduction titration (F. Bras. IV ed.) and resulted in an average value of $100.04(n=24$, samples prepared in triplicate), with RSD $0.32 \%$. The results larger than $100 \%$ may be explained by the variability of the titrimetric methods (an expanded uncertainty of $1 \%$ has been estimated for the titration assay of another analyte, as reported by Rodomonte, Montinaro, Bartolomei, 2006), and possibly also by the non-specificity of this technique, since the organic impurities usually contain moieties of similar reactivity to that of the analyte (Duewer et al., 2004; Gorog, 2005).

In the literature, at least eight different impurities are described for captopril (LGC, 2010), namely Imp. A (captopril disulfide), Imp. C ((2RS)-2-methyl-3-sulphanylpropanoic acid), Imp. D ((2RS)-3-bromo-2-methylpropanoic acid), Imp. E ((2S)-1-[2-methylpropanoyl]-pyrrolidine-2carboxylic acid), Imp. J (S-acetylcaptopril hydrate), Imp. K ((2S)-3-(acetylthio)-2-methylpropanoic acid), Imp. N ((2S,2'S)-3,3'-disulphane-diylbis(2-methylpropanoic) acid) and captopril ethyl ester. Of these impurities, two contain a sulphydryl group (Imp. C and captopril ethyl
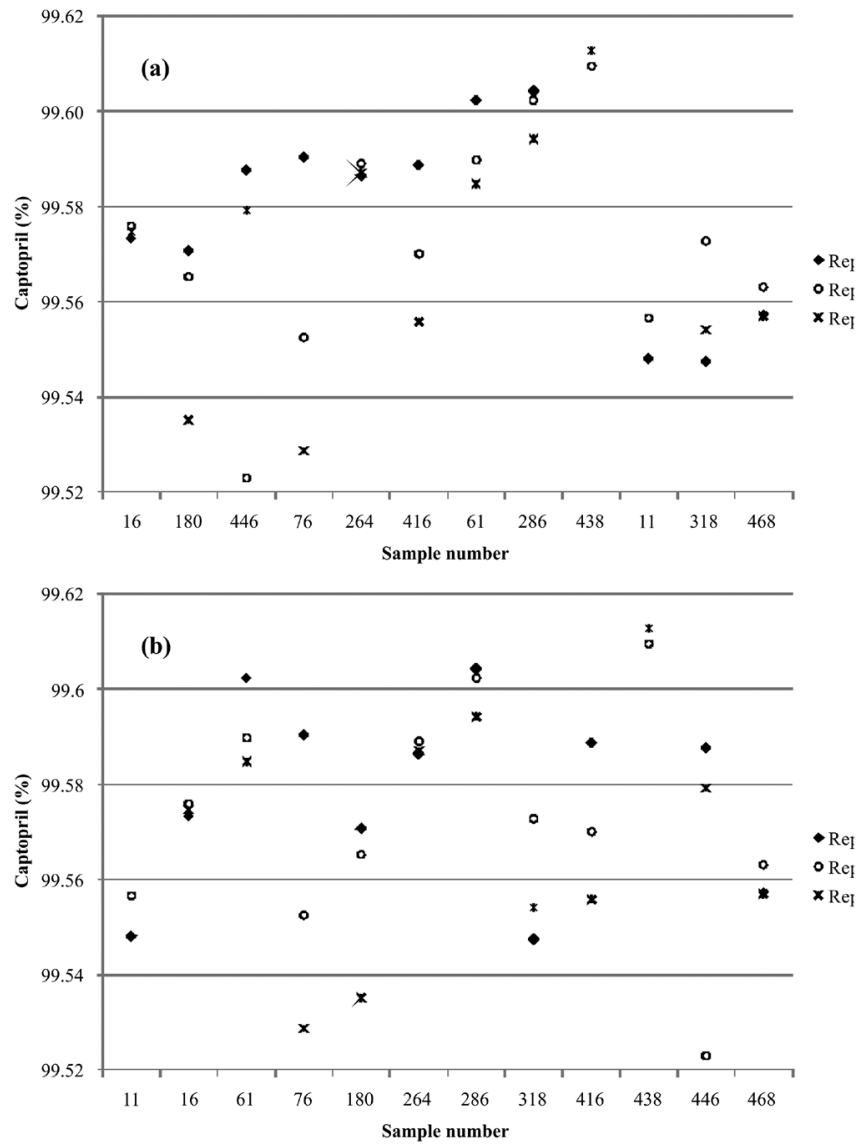

FIGURE 3 - Results for the homogeneity study: captopril contents in twelve samples analyzed in triplicate and ordered from left to the right according to: (a) the HPLC injection order; and (b) the packaging order (serial numbers). 
ester), akin to the captopril, and therefore may possibly react with the titrant.

Notwithstanding, the titration results were useful to confirm the between-bottle homogeneity of captopril CRM ( $F$ value $0.9542<\mathrm{F}$ crit 1.7568 on single factor analysis of variance). For purposes of comparison, the titration resulted in a larger $u_{b b}$ value $(0.083836 \%)$ compared to the HPLC analysis / mass balance determination.

\section{Short-term stability studies}

Short-term stability studies were performed to evaluate the stability of the captopril CRM under conditions which the material may be submitted to during transport. The study was carried out using the classical design (ISO guide 35:2006), that is, under reproducibility conditions: all flasks were subjected to $50^{\circ} \mathrm{C}$ at the same time, and then analyzed individually on pre-determined days. This type of study is expected to result in larger uncertainty values, because possible variations in the measurement system, in this case HPLC, are also included.

The reason for not using the isochronous design, which is performed under repeatability conditions (all samples analyzed in the same series) and results in smaller uncertainties and therefore is the preferred approach according to the ISO guide 35:2006, was based on the validation studies. It was observed that captopril in solution suffers degradation, with formation of increasing amounts of its dimmer, captopril disulfide. Therefore, it would not be reasonable to analyze all the samples in a single set.

The captopril contents in the short-term stability samples, calculated according to eq. 1, are shown in Figure 4, while Table IV shows the regression analysis. The $\mathrm{F}$ value less than $\mathrm{F}$ critical (or the $\mathrm{p}$-value greater than 0.05 ) confirmed the stability of the captopril CRM under transport conditions $\left(50^{\circ} \mathrm{C}, 12\right.$ days $)$.

The short-term stability uncertainty $\left(u_{s t s}\right)$ (eq. 6) was $0.005544 \%$, considering a time period of 12 days. Since this value is smaller than the long-term stability uncertain- ty (see following paragraph), it was not taken into account for the calculation of the measurement uncertainty of the certified value of the captopril CRM, as allowed by the ISO guide 35:2006.

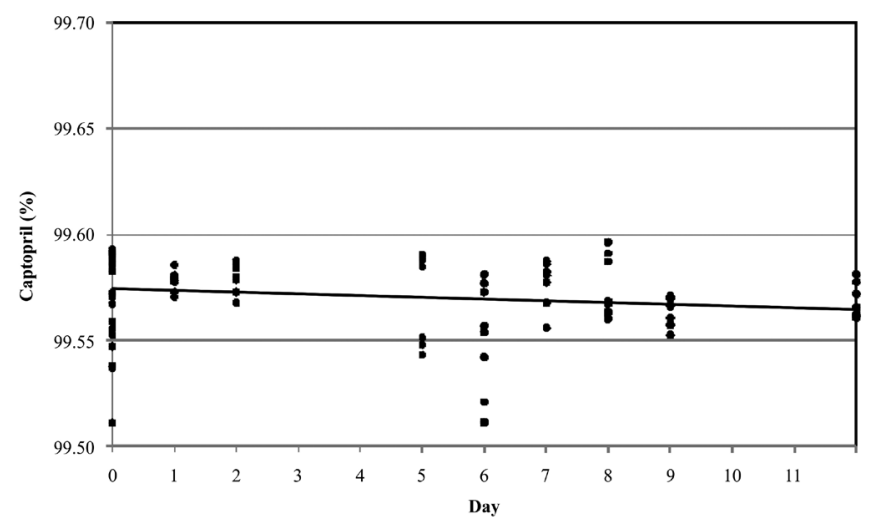

FIGURE 4 - Results for short-term stability study.

\section{Long-term stability studies}

The long-term stability studies were carried out to evaluate the stability of the CRM material under storage conditions. Table V shows the contents of related substances determined by eq. 2 and also by assay using the USP standards of captopril disulfide and of captopril (in the case of unknown impurities), following the recommendation to compare the CRM results with those obtained using (certified) reference materials (ISO guide 34:2009; Eurachem/Citac, 2000). As depicted in Table V, the two average contents did not differ significantly.

The captopril contents determined by mass balance (eq. 1) in the long-term stability study are shown in Figure 5 , while the corresponding regression analysis can be seen in Table VI. The F value less than F critical (or the p-value greater than 0.05 ) confirmed the stability of the captopril CRM under storage conditions $\left(25^{\circ} \mathrm{C}, 38\right.$ weeks).

The uncertainty associated with the long-term stability $\left(u_{l t s}\right)$ was calculated by eq. 6 and the value of

TABLE IV - Regression analysis for short-term stability results

\begin{tabular}{|c|c|c|c|c|c|c|}
\hline Source & Df & SS & MS & $\mathbf{F}$ & p-value & F critical * \\
\hline Regression & 1 & 0.001040771 & 0.00104077 & 3.065347797 & 0.083139509 & 3.9391 \\
\hline Residual & 97 & 0.032934211 & 0.00033953 & & & \\
\hline \multirow[t]{2}{*}{ Total } & 98 & 0.033974982 & & & & \\
\hline & Coefficients & Standard error & Stat $t$ & p-value & Lower 95\% & Upper $95 \%$ \\
\hline Intercept & 99.57428 & 0.002800007 & 35562.1577 & 0 & 99.56872003 & 99.5798345 \\
\hline Variable x 1 & -0.000809 & 0.000462024 & -1.7508135 & 0.083139509 & -0.00172591 & 0.000108072 \\
\hline
\end{tabular}

$* \mathrm{~F}$ crit $=\operatorname{INVF}(0.05 ; 1 ; \mathrm{df}($ residual $))$ 
TABLE V - Related substances results for long-term stability evaluation

\begin{tabular}{lccr}
\hline \multirow{2}{*}{ Test nr. } & Week & \multicolumn{2}{c}{ Related substances (\%) } \\
\cline { 2 - 4 } $\mathbf{1}$ & & Peak area ratio (eq. 2) & Assay using USP standards \\
$\mathbf{2}$ & 11 & 0.313264 & 0.389631 \\
$\mathbf{3}$ & 30 & 0.306145 & 0.285779 \\
$\mathbf{4}$ & 38 & 0.278250 & 0.256969 \\
\hline Average & & 0.321211 & 0.298205 \\
SD & & 0.3047 & 0.3076 \\
RSD (\%) & 0.0187 & 0.0573 \\
\hline
\end{tabular}

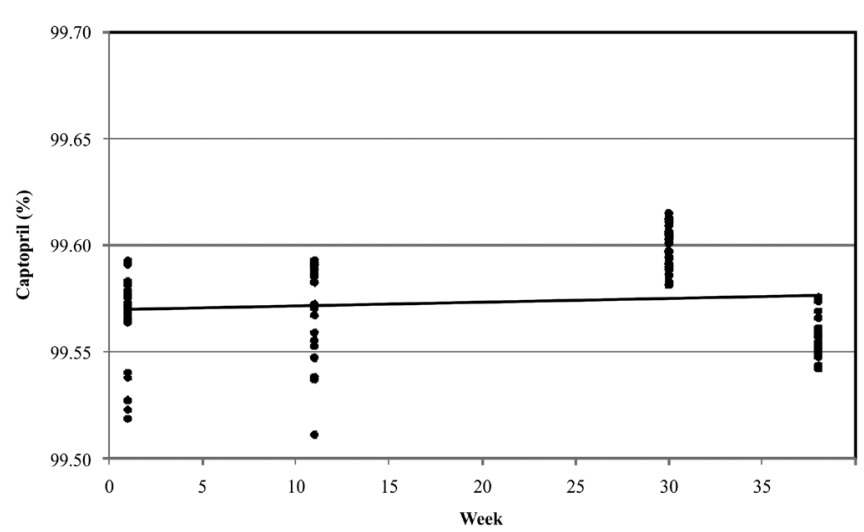

FIGURE 5 - Results for long-term stability study.

$0.024173 \%$ was estimated considering the time " $t$ " as the shelf life of 156 weeks (3 years) for the captopril CRM.

\section{CRM certified value and measurement uncertainty}

The certified value of the captopril CRM was determined by mass balance (eq. 1), using the contents of organic impurities (related substances by HPLC), inorganic impurities (residue on ignition test) and volatiles (loss on drying test), as described in the previous paragraphs. As shown in Table VII, the certified property value was $99.565 \%$ in mass fraction, the combined standard uncer- tainty associated with the CRM property value $\left(u_{C R M}\right)$ (eq. 7 ) was $0.046414 \%$, and expanded uncertainty $(U)$, using a value of 2 as the coverage factor for a confidence level of approximately $95 \%$ (eq. 8 ), was $0.093 \%$.

The magnitude of the different uncertainty contributions to the value of $\mathrm{u}_{\mathrm{CRM}}$ are shown diagrammatically in Figure 6. The largest contributions came from the determination of organic impurities $\left(u_{\text {org }}\right)$ and from the long-term stability studies $\left(u_{l t s}\right)$, followed by homogeneity uncertainty $\left(u_{b b}\right)$. The uncertainties due to the determination of inorganic impurities $\left(u_{\text {inorg }}\right)$ and volatiles $\left(u_{v o l}\right)$ were less significant.

The certified value was confirmed by Differential Scanning Calorimetry (DSC), according to the recommendation for use of one primary method or two independent secondary methods for certification (ISO guide $35: 2006$ ). The DSC can be considered a primary direct method, since it does not rely on the use of a "measurement standard for a quantity of the same kind" (JCGM, 2008), although empirical corrections may be necessary in practice (Duewer et al., 2004).

The methodology for purity determination by DSC is described by the ASTM Standard E 928-08 ("Standard Test Method for Purity by Differential Scanning Calorimetry"). This method is based on the Van't Hoff law and its derived equation (eq. 9), according to which the presence of impurities leads to the depreciation of the melting point

TABLE VI - Regression analysis for long-term stability results

\begin{tabular}{lcccccc}
\hline Source & Df & SS & MS & F & p-value & F critical * \\
\hline Regression & 1 & 0.00070209 & 0.00070209 & 1.326613296 & 0.52154865 & 3.9361 \\
Residual & 100 & 0.052923465 & 0.00052923 & & & \\
Total & 101 & 0.053625555 & & & & \\
\hline & Coefficients & Standard error & Stat t & p-value & Lower 95\% & Upper 95\% \\
\hline Intercept & 99.569813 & 0.003744131 & 26593.5715 & 0 & 99.56238447 & 99.57724097 \\
Variable x 1 & 0.0001785 & 0.000154957 & 1.151787 & 0.252154865 & -0.000128953 & 0.000485907 \\
\hline
\end{tabular}

* F crit $=\operatorname{INVF}(0.05 ; 1 ; \mathrm{df}($ residual $))$ 
TABLE VII - Captopril content in Certified Reference Material and associated measurement uncertainty

\begin{tabular}{lccc}
\hline & $\mathbf{\%}$ & $\mathbf{u}(\mathbf{\%})$ & $\mathbf{U}(\mathbf{\%}){ }^{*}$ \\
\hline Initial & 100.000000 & & \\
Related substances (organic & 0.313264 & 0.036149 & \\
impurities) & & & \\
Inorganic impurities & 0.023980 & 0.002976 \\
Volatiles & 0.097774 & 0.004889 & \\
Long-term stability & & 0.024173 & \\
Homogeneity & & 0.015181 & 0.092829 \\
Average & 99.564982 & 0.046414 & \\
\hline
\end{tabular}

* Considering a coverage factor of 2

(ASTM, 2008). It represents an accurate, fast and convenient method for substances with purity higher than $98.5 \%$.

$$
T_{S}=T_{0}-\frac{R T_{0}^{2} \chi}{\Delta H} \frac{1}{F}
$$

where: $\mathrm{T}_{\mathrm{S}}=$ actual melting temperature; $\mathrm{T}_{0}=$ melting temperature of pure compound; $\mathrm{R}=$ gas constant; $\chi=$ mole fraction of impurity; $\Delta \mathrm{H}=$ heat of fusion of pure compound; $\mathrm{F}=$ fraction of molten material, determined by measuring partial areas of fusion peak observed in DSC

Eq. 9 can be considered a first degree equation $(\mathrm{y}=\mathrm{ax}+\mathrm{b})$, in which $\mathrm{y}=\mathrm{T}_{\mathrm{s}} ; \mathrm{a}=-\mathrm{R}\left(\mathrm{T}_{0}\right)^{2} \chi / \Delta \mathrm{H} ; \mathrm{x}=1 / \mathrm{F}$; $\mathrm{b}=\mathrm{T}_{0}$. Normally the graph from $\mathrm{T}_{\mathrm{S}}$ versus $1 / \mathrm{F}$ does not exhibit strict linear behaviour. The linearization is accomplished by adding an arbitrary area $(\mathrm{c})$ to the total peak area $\left(\mathrm{A}_{\text {tot }}\right)$ and to each partial area $\left(\mathrm{A}_{\text {part }}\right)$, as shown in eq. 10 .

$$
F=\frac{A_{\text {part }}+c}{A_{\text {tot }}+c}
$$

The ASTM standard E 928-03 provides two methods for purity calculation according to the Van't Hoff law equation. For "method A" used in this study, the software TA Universal Analysis 2000 (TA Instruments) was employed for the calculations. The value of $\mathrm{c}$ is determined using the nonlinear least squares technique and then used for the linearization of the curve $T_{S}$ versus $1 / F$. The linear and angular coefficients are estimated by linear regression. Finally, the mole fraction of impurities in each sample is determined from the angular coefficient.

Figure 7 shows the DSC curve obtained for captopril CRM. During captopril heating, a well-defined and symmetric endothermic peak was observed, which is typical of a constant temperature melting transition. In addition, the

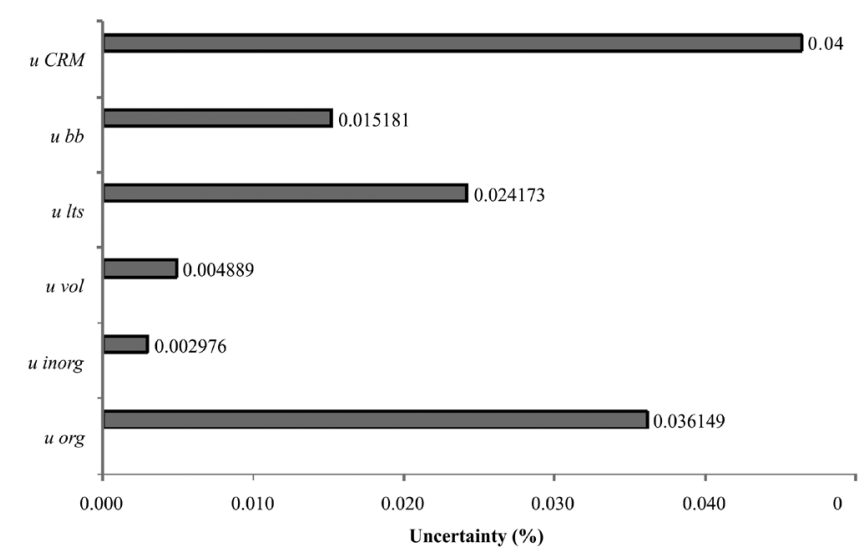

FIGURE 6 - Uncertainty contributions.

baseline was maintained, suggesting that the heat capacity of the material does not change during the process. Furthermore, there was no other phase transition during the DSC scan. Therefore, the material presented ideal conditions for purity calculation by the ASTM standard method.

The captopril content determined by DSC was 99.65 $\pm 0.023 \% \mathrm{~mol} / \mathrm{mol}$, demonstrating that the purity of analytes with a known impurity profile, such as captopril CRM, can be determined equivalently by DSC and HPLC (Moreira et al., 2010). Another study also indicated that the purity obtained by DSC is comparable to the purity determined by HPLC in case of organic compounds with at least $98 \%$ purity (Mathkar et al., 2009).

The captopril content of the CRM determined by titration, according to the assay procedure described in the F. Bras. IV. ed., was greater than 100\% (100.04\% + $0.32 \%)$. Therefore, although the use of titration, a primary direct method (Duewer et al., 2004; Gorog, 2005; ISO guide 35:2006), would be more recommended to determine the property value of captopril CRM, it proved to be less indicated for certification compared to the mass balance approach. 


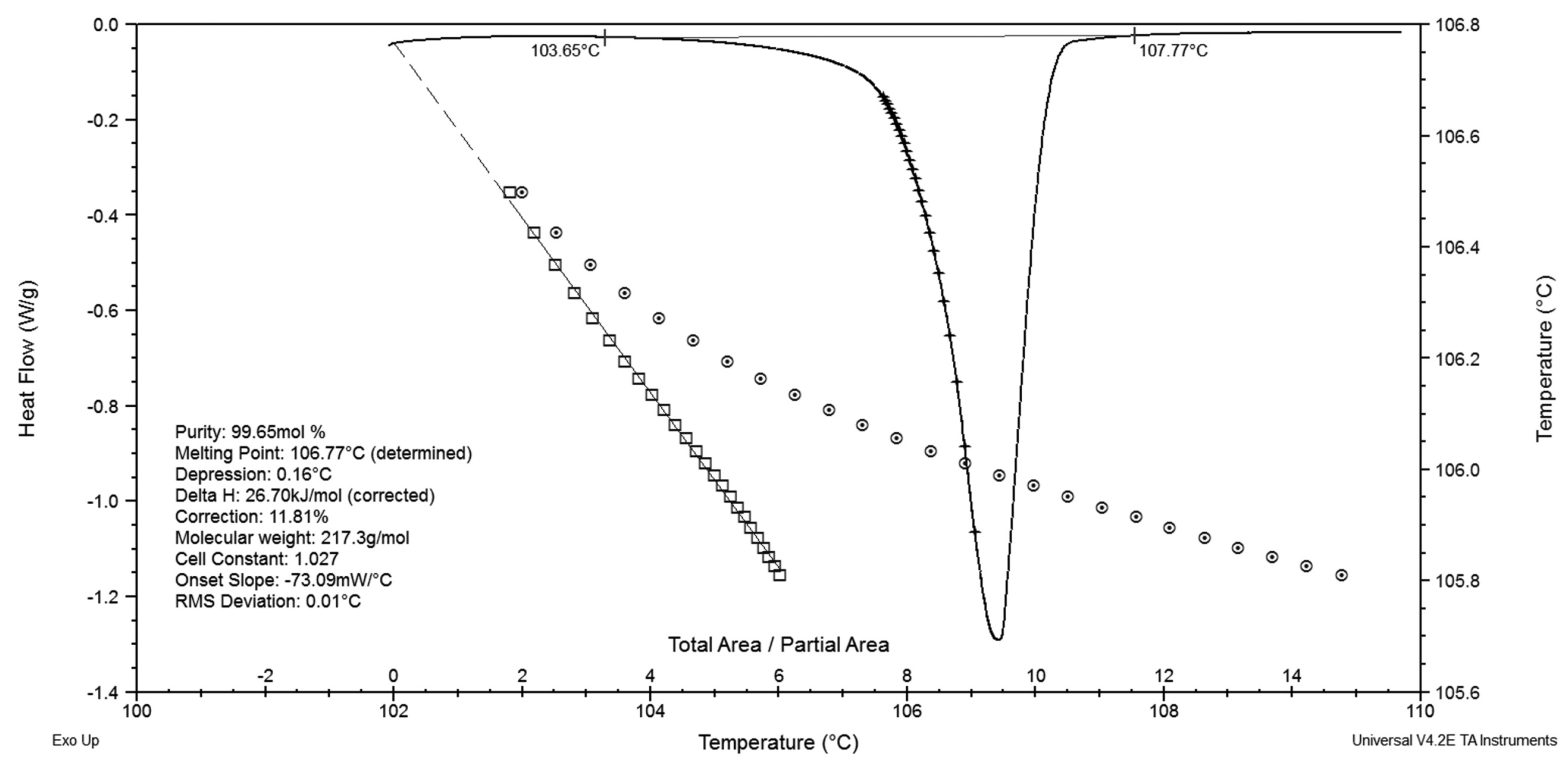

FIGURE 7 - DSC curve for captopril CRM in the $100-115^{\circ} \mathrm{C}$ range (heating rate of $0.5^{\circ} \mathrm{C} / \mathrm{min}$ ) and inert atmosphere (He, $50 \mathrm{~mL} / \mathrm{min}$ ). Curves and values generated by the software TA Universal Analysis 2000 for calculation in purity determination.

\section{CONCLUSIONS}

The candidate Certified Reference Material (CRM) of captopril, the first Inmetro batch, has been certified. The certified reference value and expanded uncertainty $(U)$, using the value of 2 as the coverage factor for a confidence level of approximately $95 \%$, was $99.565 \pm 0.093 \%$ in mass fraction.

Captopril CRM is the first Brazilian Certified Reference Material in the pharmaceutical area and allows analytical laboratories and research institutes to obtain traceable measurements, in compliance with the ISO 17025:2005 requirements.

\section{ACKNOWLEDGEMENTS}

The authors would like to thank "Cristália Produtos Químicos e Farmacêuticos Ltda" and "Medley S. A. Indústria Farmacêutica" for their support.

\section{REFERENCES}

AMERICAN SOCIETY FOR TESTING AND MATERIALS INTERNATIONAL. ASTM Standards E 928-08. Standard test method for purity by Differential Scanning Calorimetry. Pennsylvania: ASTM International, 2008, 7 p.

\section{ASSOCIAÇÃO BRASILEIRA DE NORMAS TÉCNICAS.} ABNT NBR ISO/IEC 17025:2005. Requisitos gerais para competência de laboratórios de ensaio e calibração. Rio de Janeiro: ABNT, 2005. $31 \mathrm{p}$.
ASSOCIAÇÃO BRASILEIRA DE NORMAS TÉCNICAS / INSTITUTO NACIONAL DE METROLOGIA, NORMALIZAÇÃO E QUALIDADE INDUSTRIAL. Guia para a expressão da incerteza de medição. 3.ed. (revisada). Rio de Janeiro: ABNT/Inmetro, 2003. 120 p.

DUEWER, D.L.; PARRIS, R.M.; WHITE, E.V.; MAY, W.E.; ELBAUM, H. An approach to the metrologically sound traceable assessment of the chemical purity of organic reference materials. National Institute of Standards and Technology Special Publication 1012. Gaithersburg: National Institute of Standards and Technology (NIST), 2004. 53 p.

EURACHEM/COOPERATION ON INTERNATIONAL TRACEABILITY IN ANALYTICAL CHEMISTRY. EURACHEM/CITAC Guide CG 4. Quantifying uncertainty in analytical measurement. 2.ed. London, 2000. 120 p. Available at: <http://www.eurachem.org/guides/pdf/ QUAM2000-1.pdf $>$. Accessed on: 10 jun. 2010.

FARMACOPEIA BRASILEIRA. 4.ed. São Paulo: Atheneu, 2002. p.2.,181.

GOROG, S. The sacred cow: the questionable role of assay methods in characterizing the quality of bulk pharmaceuticals. J. Pharm. Biomed. Anal., v.36, n.5, p.931937, 2005.

HOFER, J. D.; OLSEN, B. A.; RICKARD, E. C. Is HPLC assay for drug substance a useful quality control attribute? $J$. Pharm. Biomed. Anal., v.44, n.4, p.906-913, 2007. 
INTERNATIONAL CONFERENCE ON HARMONISATION OF TECHNICAL REQUIREMENTS FOR REGISTRATION OF PHARMACEUTICALS FOR HUMAN USE (ICH). ICH harmonised tripartite guideline. Validation of Analytical Procedures: text and methodology. Q2(R1). Current Step 4 version. Parent Guideline dated 27 October 1994. Complementary Guideline on Methodology dated 6 November 1996 incorporated in November 2005. Available at: $<$ http://www.ich.org/LOB/media/MEDIA417. pdf. $>$. Accessed on: 01 jul. 2009.

INTERNATIONAL ORGANIZATION FOR STANDARDIZATION. ISO guide 30 . Terms and definitions used in connection with reference materials. Geneve, 1992. 8 p.

INTERNATIONAL ORGANIZATION FOR STANDARDIZATION. ISO guide 30 / Amd. 1. Terms and definitions used in connection with reference materials. Amendment 1. Revision of definitions for reference material and certified reference material. Geneve, 2008. 2 p.

IN TERNATIONAL ORGANIZATION FOR STANDARDIZATION. ISO guide 34. General requirements for the competence of reference material producers. Geneve, $2009.34 \mathrm{p}$.

IN TERNATIONAL ORGANIZATION FOR STANDARDIZATION. ISO guide 35. Reference materials - general and statistical principles for certification. Geneve, $2006.64 \mathrm{p}$.

JOINT COMMITTEE FOR GUIDES IN METROLOGY (JCGM). International Vocabulary of Metrology: basic and general concepts and associated terms (VIM). JCGM 200:2008. 3.ed. Sèvres (France): BIPM, 2008. 90 p. Available at: <http://www.bipm.org/utils/common/ documents/jegm/JCGM_200_2008.pdf.>. Accessed on: 26 jun. 2010.

KUSELMAN, I.; WEISMAN, A.; WEGSCHEIDER, W. Traceability without uncertainty: current situation in the pharmaceutical industry. Accred. Qual. Assur., v.8, n.11, p.530-531, 2003.
LE GOFF, T.; WOOD, S. Improvement of the traceability of reference materials certified for purity: evaluation of a semi-preparative high-performance liquid chromatography approach. Anal. Bioanal. Chem., v.394, n.8, p.2183-2192, 2009.

LABORATORY OF THE GOVERNMENT CHEMIST (LGC) STANDARDS. Pharmaceutical Reference Substances and Impurities 2010 / 2011. Teddington: LGC, 2010. 421p. Available at: $<$ http://gcstandards.com/media/559600807. pdf. $>$. Accessed on: 29 sep. 2010.

MATHKAR, S.; KUMAR, S.; BYSTOL, A.; OLAWOORE, K.; MIN, D.; MARKOVICH, R.; RUSTUM, A. The use of differential scanning calorimetry for the purity verification of pharmaceutical reference standards. J. Pharm. Biomed. Anal., v.49, n.3, p.627-631, 2009.

MOREIRA, G.F.; BALBO, A.; ACHETE, C.A.; BARIN, J.S.; WOLLINGER, W., NOGUEIRA, R.; BITTENCOURT, C.F.; RODRIGUES, J.M. Aplicação da calorimetria exploratória diferencial (DSC) para determinação de pureza de fármacos. $P \& P$, v.11, n.1, p.22-29, 2010.

RODOMONTE, A.L.; MONTINARO, A.; BARTOLOMEI, M. Uncertainty evaluation in the chloroquine phosphate potentiometric titration: application of three different approaches. J. Pharm. Biom. Anal., v.42, n.1, p.56-63, 2006.

SMITH, R.J.; WEBB, M.L., (Eds.). Analysis of drug impurities. Singapore: Blackwell Publishing, 2007. p.12.

STULZER, H.K.; SILVA, M.A.S. Estudo de estabilidade de grânulos revestidos e comprimidos contendo captopril. Acta Farm. Bonaer., v.25, n.4, p.497-504, 2006.

UNITED STATES PHARMACOPEIAL CONVENTION. Available at: $<$ http://www.usp.org $>$. Accessed on: 21 apr. 2010.

WILLIAMS, R.L.; PROJECT TEAM 4. Official USP Reference Standards: Metrology concepts, overview, and scientific issues and opportunities. J. Pharm. Biomed. Anal., v.40, n.1, p.3-15, 2006.

Received for publication on $29^{\text {th }}$ June 2010. Accepted for publication on $20^{\text {th }}$ Oct 2010. 